\title{
Mytologen Grundtvig
}

\author{
Et foredrag
}

\author{
Af Jorgen Elbek
}

Spurgte man en beboer af dagens Danmark hvad hans sjæl eller det psykiske $\mathrm{i}$ ham består af kunne han vel tænkes at svare: fornuften hører i hvert fald med blandt de sjælelige evner, men fornuft gør det ikke alene, der vil også altid være nogle følelser med i spillet. Som fremtrædende repræsentanter for den opfattelse kan man, nærmest i flæng, nævne diplomaten Erik Scavenius som mente at $\mathrm{i}$ politikken måtte fornuften komme først, i litteraturen følelserne, sprogforskeren Louis Hjelmslev som hævdede at der i hans såkaldte rationelle humanisme ikke lå nogen fornægtelse af følelsens ret, og forfatteren Svend Åge Madsen som engang $\mathrm{i}$ sin ungdom sagde at han hellere så sine bøger læst med følelserne end med forstanden.

Der tales altså gennemgående om to tyngdepunkter i sjælens væsen, men går vi tilbage $\mathrm{i}$ tiden og/eller til mere skjulte talsmænd, viser der sig i stedet for tre. Rudolf Steiner, som jeg kun kender på anden hånd, siges at regne med følelse, forstand og vilje. Hans læremester Goethe opstiller i sin eventyrfortælling "Das Märchen" en guld-, en sølv- og en kobberstatue som står for die Weisheit, der Schein og die Gewalt - idet visdommen vel er en gylden udgave af fornuften, skinnet muligvis betegner en synlig, sølvskinnende fremtrædelsesform som følelsen må have at knytte sig til, og magten måske vil sige det råstof, den kobbermalm som viljen må betjene sig af og arbejde i. Middelalderteologer som Augustin og Bonaventura skelner mellem memoria, intellectus og voluntas - evnen til at modtage, danne og - ikke mindst - bevare forestillingsbilleder; evnen til at drage slutninger; og evnen til at overveje og træffe sine valg. Og oldtidsfilo-

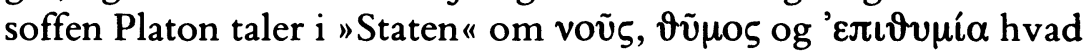
der - dristigt, men rigtigt, - kan oversættes med: den sjæl der bor i hovedet, den der vælder op, svulmer og flammer i brystet, og den der driver de begærende organer. 
Ser vi nu tilbage over de forskellige sjælelige treheder, står det klart at fornuften går igen $\mathrm{i}$ dem alle, det er så at sige den der laver dem, mens de to andre led fremtræder langt mere skiftende så at følelsen snart vender indad og knytter sig til minder, snart bliver kernen $\mathrm{i}$ al virksomhed der går ud over dagen og vejen tænk på den nordiske mytologis modstilling af dådrige aser som Tyr og Tor og blide vaner som Freja og Frej - og de legemlige lyster tilsvarende snart ses som rene forbrugere, gavnløse ædere, snart bliver til selve den lyst der driver værket, prøvestenen for om man kan stå ved sine valg og følge sine beslutninger op i gerning - tænk på de dorske jætter over for de flittige dværge: (På folkevisesproget betyder "vilje" også begær - ligesom will $\mathrm{i}$ xldre engelsk -: for hun fremmed ikke hans vilje - hun ingen god vilje af mig fik). Endvidere synes det særlig at være religiøse tænkere der ser treheder som for de kristne af dem hænger sammen med at mennesket skabtes $i$ billedet af den treenige gud hvis egenskaber, fordelt på faderen, sønnen og helligånden, teologisk bestemmes som magt, visdom og kærlighed - hvad der genkalder den antikke treklang det skønne, det sande, det gode.

Således også for Grundtvig hvis salmer genlyder af lys, kraft og varme, og hvis historiske skrifter bygger på en fast tredeling af menneskehedens levnedsløb i en fantasiens, følelsens og forstandens tid, svarende til ungdom, manddom og alderdom. Men er tænkningen i treheder over alt dunkel, så er den det hos Grundtvig endnu mere fordi han øjensynlig ikke stemmer overens med sig selv, for omend lys svarer meget godt til forstand og varme passer med følelse, så er det svært at se kraft og fantasi som eet og det samme, også selvom man taler ældre dansk og kalder fantasien for indbildningskraft. Men netop i dunkelheden har Grundtvigs livslange arbejde med mytologien sin plads; som nordisk og senere også græsk mytolog fandt han mulighed for at sige hvad han ikke kunne udtrykke ligefremt, men som dog lå ham på sinde - og hvad det var, vil jeg prøve at formidle ved at følge hans arbejde gennem dets mange faser.

Det var gudelæren der gav Grundtvig selve det stød der satte ham igang som offentlig skribent. Omkring 22 år gammel forelskede han sig $i$ en kvinde som han ikke fik, men var tvunget til at se dagligt, og det betød på den ene side en revolution $i$ hans forståelse af tilværelsen, en eksplosiv udvidelse af hans opfattelse 
af sig selv og omverdenen, på den anden side en højst ubehagelig prøvelse, en nærgående, yderst følelig anfægtelse af kødelig art, som hvis han giver efter for den ligesom "omspænder ham med furiers bælte". Den dobbelthed så han nu fandtes udtrykt i det oldnordiske sæt af religiøse forestillinger hvor guder er i krig med trolde, aser med jætter, og han kan for sig selv hilse sin elskede som følger:

As eller jette, som med usynlige hånd mægted at flette

om mig det lønlige bånd ...

Det svarer til at han skiftevis kalder sin dame for åbenbaringen, "et billede af den evige", og for "tryllerinden", eller på vers tvedeler den ild hun indgyder ham i en der kommer oppefra og en der kommer nedefra:
$\mathrm{Du}$, den vidunderlig høje, en guddoms forblommede lyd, som fra det sollige øje nedstråler himmelens fryd, og fra det ildlige øje nedlyner helvedes $\mathrm{kval}$...

Således er Grundtvig nu selv blevet kampplads for, lægger selv krop til den strid mellem guder og jætter som ender med ragnarok - den krig i hvilken Villy Sørensen i sin kvikke og underfundige ragnaroks-bog har genkendt supermagternes koldkrig. Umiddelbart genfinder Grundtvig sin situation i myten om kærligheden mellem guden Frej, der nok boede blandt aserne, men som sin søster Freja var af vanernes mere blødagtige slægt, og så jættepigen Gerda. Hun ligesom lyser af sig selv, ud af legemets ild, og fordunkler derved den himmelske sol, og Frej må for at få hende bortgive sit sværd - som han vil komme til at savne i ragnarok hvor han skal kæmpe mod ingen anden end ildjætten eller vulkandjævelen Surt - som ved det sidste store udbrud på Island omsider fik sig en ø, Surtsey. I vanen Frej så Grundtvig faren for at blive et bytte for sit begær, for at synke hen i smertefuld længsel, isprængt ilinger af vellyst. 
En foreløbig redning fandt han ved at gøre fælles sag med en af de rigtige aser, nemlig Odin. Om ham fortælles der i et kvad at han har ofret sig, ved at såre sig med sit spyd og hænge ni nætter over jorden i træet Ygdrasil - navnet betyder Odins hest og Grundtvig vil nu i sin ungdoms vår "frembære sit liv som et offer til Norden ": han opgiver at tænke på jordisk lykke og regner sig for "mærket med spydsodden". Til gengæld giver Odin, som i kraft af sit indvielsesoffer er skjaldenes gud, ham som gave den oplevelse at

Da løses fra jorden

det fængslede blik.

Og det betyder at den kærlighedssyge naturstemning som trænger sig på hos den ulykkelige elsker når han søger ud i det milde, ødanske landskab for at lindre sin $\mathrm{kval}$, den viger for en opfattelse hvor naturen får mening, betydning, nemlig som et billede på eller spejling af noget større: duggen der perler i aftenluften her og nu rinder fra føromtalte fjerne og uhåndgribelige Ygdrasil som nornerne, skæbnegudinderne der styrer tidens forløb, overøser med vand for at holde træet friskt:

Historie da og natur sig forene

i sluttede favn under Yggdrasils grene.

Her mødes da hans tankegang og hans sansning, hans drift og hans bevidsthed, og i denne luftige forening, dette billedlige favntag finder kærlighedstrangen da hvile, - så længe det nu kan vare og fantasien strækker til.

Udover at være digtningens gud er Odin også visdommens, den af alle aserne der klarest ser at nornerne leder tidens gang frem mod ragnarok hvor både guder og jætter skal gå til grunde. Det vil sige at ved at binde sig så stærkt til Odin har Grundtvig holdt sig det midlertidige $\mathrm{i}$ sin løsning for øje. Hans såkaldte "asarus " er så udpræget en betagelse af og bevidsthed om asadramaets helhed, og hvad skal der så blive af ham når Odin som han spejler sig $\mathrm{i}$ går til grunde, slugt af Fenrisulven - som var af jæetteslægt men blev opfødt i Asgård, bandtes ved list og fik et opretstående sværd mellem sine kæber? (Jeg tør måske her ind- 
skyde det private bidrag til Fenris' tolkning at jeg ofte har drømt om en hund som vil bide mig, men hvis kæber jeg så, uden egentlig angst, men umådelig træt og bekymringsfuld, holder fra hinanden med hænderne).

Grundtvigs personlige ragnarok indtraf nogle år senere da han for første gang i sit liv måtte valge. Hidtil havde alt drejet sig om at bjærge livet og redde sig som han bedst kunne, men nu løb han, under ganske andre omstændigheder end $\mathrm{i}$ forelskelsens frembrud, ind i en situation hvor to muligheder stod ham åbne: han kunne forfølge sin karriere som tegnede lovende, eller han kunne på ubestemt tid ofre sig for sine gamle forældre der udbad sig hans hjælp. Stående overfor valget opdagede han at de mytiske luftlag han havde levet sig ind $i$ og styrket sig ved at indånde, de gav ikke noget fodfæste her og nu. Han havde ladet sit "hjerte vorde koldt", som han i sin krisebevidsthed sagde, d.v.s. i sin lidenskabs nød skåret forbindelsen til de levende mennesker over og i stedet knyttet sig til uvirkelige genspejlinger af visse væsentlige sider hos ham selv. $\mathrm{Nu}$ stillede folelsen ham over for sine fordringer $i$ en sådan grad at han følte djævelen spænde sig om hans krop som en slange, og dette at "lys uden varme var helvedes kval " - som han senere skrev - slog ham hjem til en gammeldags kristentro hvori alle de nordiske guder og derés modstandere gik under, som i ragnarok.

I virkelighedstroskabens navn skifter den 27-årige Grundtvig nu sin umulige kærlighed ud med den forlovelse som gennem alle årene havde kunnet lade sig gøre - et skridt der kom til at hvile som en tynge på begge parter den næste menneskealder. Samtidig og i samme ånd går han fra mytologien over til historien. Også her bliver han, men efter nogle år dukker myterne så småt frem igen, nu fra en anden kant. Sagen er at han kører fast $i$ enhver historikers genkommende problem: det er fortiden han skal kaste lys over, men nu- eller fremtiden han skal gribe ind $i$. Grundtvig gik ind til sit årelange arbejde med den norske Snorre, den danske Saxo og den oldengelske Bjovulfsdrape. Men efter eget senere udsagn fik han ikke så meget gravet historien op, som sig selv ned: han foretog en uddybning for at lægge krønikerne frem for sine medlevende, men sank selv i graven. Samtidig får han dog alligevel kastet en líne ud til fremtiden, og det sker gennem ragnarokmyten som siger at når den gamle 
verden er gået under skal en ny rejse sig af havet. Når han kalder en digtsamling fra den mørke tid op efter Heimdal, så er det fordi denne lyse as, gudernes grænsevagt, skal støde i luren som signal til undergangskampen - og desuden bærer han tilnavnet "bølgernes søn" hvad der jo minder om en ny jord der stiger af vandet med en ny og renere slægt. Tor som han ikke tidligere har gjort meget ud af, vil han nu, frit digtende ud fra kilderne, have formælet med Freja så at styrken og kærligheden kan mødes mens hendes bror Frejs kærlighed jo betød en svækkelse. Sammen skal de to avle en søn, som

rykkes bort fra jorden

alt $\mathrm{i}$ den sidste torden

og lyner ned igen.

- hvad der rimer med overleveringen som siger at Tors afkom skal leve i den ny verden efter ragnarok og "finde asernes guldtavl i græsset «. Skjult tolkes her Grundtvigs håb om at Norge som vi havde mistet i 1814 og afstået til den svenske krone må finde tilbage til Danmark, som Tor til Freja, og de sammen skabe en ny tid mens Sverrig og jættehjem græmmer sig.

I disse år bliver Grundtvigs forrige hovedgud til Nornegæst, det navn hvorunder Odin fortælles at have opsøgt kristne middelalderkonger for at lokke dem tilbage til hedenskabet. Men den danske skjald tager ham ikke som et tegn til tilbagefald, ser i ham tværtimod forvarslet om et fornyet og forynget Danmark hvor hedensk kraft og kristen kærlighed bliver ét. Det kan han gøre fordi Nornegæst også er en offerskikkelse og som sådan altså af kristen art, fra fødslen udstyret med en kerte af træ som han kun kan leve så længe er til, et livslys som han selv ender med at sætte i brand.

Som man ser, nærmer mytologen og historikeren Grundtvig sig hinanden ved at de gamle guder ikke længere alene udtrykker størrelser og strømninger $\mathrm{i}$ hans sind, men også tilforordnes Nordens folkestammer - Tor nordmændene, Freja danskerne, og at svenskerne og jætterne bliver ét fedt, er ikke så slemt som det lyder, men nærmest en midlertidig ordning, for Sverrigs egentlige indvånere er ikke så meget svenskerne som goterne. Dem ærer Grundtvig ved at oversætte kvadet om Bjovulf, deres 
konge, og de udledte deres navn og herkomst fra selveste Odin, med tilnavnet Gaut. Gennem norsk, dansk og gotisk dæmrede et grundtvigsk billede af "trillingefolket i Nord " som var kommet for at blive ...

Fyrre år gammel forkynder Grundtvig med et at nu håber han som aldrig før på et "kærligt ægteskab mellem Tor og Freja ". Det hænger sammen med at der ud af kraften og varmen har tændt sig et lys - hvilket først skete da alle de udveje han kunne tænke sig til havde lukket sig om hans betrængte sind. Solen havde han set bort fra siden den i sin tid svøbte sig om pigen så han måtte vende sig væk, i stedet havde der været myternes stjerneskær og måneskinsarbejdet $i$ historiens grav, men nu randt den frisk og forynget op af havet, Hejmdals fødested og den ny jords vugge, for natten var forgangen og dagen kommet nær.

Det står altsammen i det store digt Nyårsmorgen, og her viser det sig også at det kærlige ægteskab åbnes med et tredobbelt bryllup:

Ja, Sol i det høje!

Ej du, som nu staar

Støvhytter for $\varnothing_{\mathrm{je}}$

Med Dødningekaar,

Men du, som har straalet

I Kraft og med Glans,

Da Ordet var Maalet

For Syn og for Sans,

Dig vilde jeg love

Som Fuglen i Skove,

Som Stjerner i Dagenes Gry!

Og, dejlige Maane!

Ej du, som med Il

Maa stjæle, maa laane

Dit Dødningesmil,

Men, du som har luet

Saa lun og saa klar,

Da Aanden blev skuet

Som Ild under Glar,

Dit Ny og dit Næde

Er værd at omkvæde,

Ej Bytte gør du paa Bedrag! 
Thi bandt jeg dig gerne Af Straaler en Krans, Højhellige Stjerne, Som skjuler din Glans! Du Sol under Dække, Lysbilled af ham,

Der sig lod paalægge

Vort Aag og vor Skam, I Støv sig lod svøbe,

For Støvet at døbe, At klare med Ild og med Aand!

Fuldværd at omkvæde Og kalder jeg dig, Som favner med Glæde, En Bølge saa lig, Ydmygelig Varmen Af Solen bag Sky

Og føder i Barmen

Da Lyset paa ny, Du Skabning af Aanden, Af Gudhjerte-Haanden, Du dejlige Maane i Løn!

I Stjerner fuldmange, Som knæle i Sky Med jublende Sange, Naar Skyggerne fly, Naar Solen med Styrke Opstiger af Hav, Og levner kun Mørke En lysnende Grav, Gid I vilde bære Mig Kvad til hans Ære, Som kalder hver Stjerne ved Navn!

Da skulde jeg lære, Hvad faa ikkun veed, I Runer fuldsære! Med eder Besked, Som Tidender føre Om Solstraale-Rov 
Paa Aarvaagers Øre,

Paa Alsviders Hov,

Paa Skjoldet hint tykke

Af Sky og af Skygge,

Som mørkner den strålende Gud!

Brudefærdens første par møder vi i de første to strofer som handler om Jesus og den apostolske menighed. De befinder sig i luften hvor Odin tidligere red på sin ottefodede hest med udsigt til engang at blive slugt af "egennyttens ulv", solen står $i$ det høje og er Kristus, og månen der er dejlig som en kvinde luer ud af pinseunderets ildtunger der sad på apostlenes isse. Næste par som også fylder næste strofepar er Kristus som han er til stede i eller iblandt os som skrevet står, usynlig men virksom, og så hans troende som favner ham på kvindevis - et møde som i den store verden finder sted i plan med vandet - en bolge så lig - og i menneskets lilleverden på tilsvarende niveau: $i$ barmen. Sidste par - se de to sidste strofer - er alt det vi før har omtalt, udtrykt gennem stjernerne som frembærer kvad, og det solformørkende måneskjold der fører tidender - altså mytepoesi og historie, som nu henholdsvis kneler og er noget mørkt og fast. De lag i sig hvor så mangen anden en huser lyst til mad og mange piger, $i$ dem har Grundtvig nu fået kulet hele sin ungdoms- og manddomstids dannelse ned.

I erkendelse af at dette bærende plan i digtet kunne være svært tilgængeligt skrev Grundtvig en udførlig realkommentar som dog ikke blev trykt. Heri kan man bl.a. læse, at Årvåger og Alsvider er solens heste og - mere betydningsfuldt - at aserne er "Nordens guder som betegne alle hovedstykkerne af den cedlere menneskenatur" og at jætterne er "iskolde og hundekloge og bestandig kun tænker på sig selv «. Hvad de ædlere dele angår, så var Tor "den forgudede heltekraft, den nordiske Messias, og alt viser at Norge er hans rette hjem, ligesom Danmark Freis og Angelsachsen Odins ... hvilken mageløs skat Norden har i sine myter som klarlig afbilde de nordiske heltestammer $i$ hele deres ejendommelighed, og derfor tillige deres stærke drømme, deres dristige håb og dybe ønsker «. Odin, Frej, Tor - kraft, varme, lys - drøm, ønske, håb ... eller fantasi, følelse, forstand - ånd, hjerte, ord. Mest overraskende er sidste led i trillingerækken. Først hav- 
de Grundtvig skudt Frej til side og sluttet forbund med Odin, så havde han ladet mytefantasien og de poetiske drømmerier fare, knyttet sig til det nærværende, og efterhånden som han følte kraften gå af sig, søgt styrkelse i fabler om kraftkarlen Tor. Men da så vanskelighederne har løst sig, gennembruddet fundet sted, viser det sig at hvad han savnede ikke var kræfter, men indsigt, lys, forstand på at bruge dem og viden om hvorfor. Som et forvarsel om lysets fødsel - og ikke i medfør af sine svulmende muskler - blev Tor håbets gud, den nordiske Messias - en sammenhæng som Grundtvig sådan set længe havde været klar over idet han tidligt gjorde "løgnen i naturen " til ét med Midgårdsormen, verdenshavets slange som Tor kæmper mod og som er i slægt med de slanger Grundtvig følte sig omsnoet af under sine kriser - hvorved Tor jo får sandheden på sin side og genspejler Kristus som sagde: "Jeg er sandheden ".

"Lys og varme når de kun er begge xgte lade sig ej blot forene, men udgør i grunden eet " skrev Grundtvig i forbindelse med Nyårsmorgen, men da han en årrække senere fik et nyt gennembrud med den berømte Nordens mytologi 1832, var det snarere enheden af lys og kraft der foresvævede ham - eller "det levende ord der løber ud i eet med ånd «. I mellemtiden er gamle Odin som nu mere er klogskabens end skjaldskabets gud blevet den der udtrykker håbet, vel at mærke ikke den nu aldrende Grundtvigs personlige håb, som var knyttet til Kristus, men det håb som han var rede til at dele med sit folk og som gjaldt den fælles fremtid, et håb som efter sit guddommelige tilhørsforhold at dømme mere var en stærk drøm - en fantasi, en vision, en utopi - end det just var sandt. Og ligevægten mellem aser og vaner - ægteskabet mellem Tor og Freja, - er forrykket til fordel for de første, så at det nu bliver de kampkraftige guder der tegner Nordens ånd som er en kæmpeånd. Dog lægges snoren stadig af strenge tre, både $\mathrm{i}$ den store og $\mathrm{i}$ den lille verden som svarer til hinanden, "thi det er fantasien som forbinder og forstanden som adskiller, medens følelsen vekselvis, som kærlighed og had, snart forbinder og snart adskiller, som det afbildes for vore øjne ved himlen, der omhvælver det hele, havet, der både adskiller og forbinder, og jorden, der er de utallige skikkelsers moder". Hvad den nordiske kraftfuldhed mangler, må derfor hentes ind fra syden i form af skønhed, historie og natur skal favne 
hinanden $i$ et kulturforbund mellem Skandinavien og Grækenland hvis mytologier i alle måder er "hinandens fylde". Tor skal nu ikke giftes med Freja, men med den græske Sibylle - vist mest fordi Grundtvig har forelsket sig i en smuk og begavet engelsk dame som - så kort tid efter Lord Byrons død i deres frihedskrig - kan tænkes at have talt grækernes sag (ifølge mundtlig meddelelse fra Kaj Thaning).

Med de græske guder inden for sin synsrand kan Grundtvig nu helt udfolde de forbindelser mellem naturens og sjælens elementer som han er nogenlunde ene iblandt os danskere om at kende: "Zeus, ... indtager himlen, har lynet til sit våben og ørnen til sin fugl; thi således er det jo med fantasien, ungdommens genius [som er højtflyvende og ærelysten]. Havet hos grækerne var symbolet for følelsen i det hele, moder både til Achilles og Afrodite ... det var den stormende lidenskabelighed der bringer alle andre følelser til tavshed de i Poseidon forgudede. Pluto [= Hades som har sit rige under jorden $].$. har ... det opløsende der er hovedelementet i forstandens virksomhed ... målet, staven og nøglen er hans, som reflexionens eller eftertankens symboler". Skjult tegnes her et naturligt levnedsløb der er som en stadig synken, så at forstanden ender i nederste lag, et langt fald som svarer til den velkendte, med årene stigende materialisme. Som for om muligt at bryde den nedadgående linie stiftes forbundet mellem fantasiens kraft og forstandens lys, og den frugt det sætter - så at sige hans nye program - finder han ligger $\mathrm{i}$ myten om den dejlige Persefone, som blev røvet af Hades, men dog fik lov at være hos Zeus en del af året.

And er for sjælen hvad ånde er for legemet, siger Grundtvig et sted, og når han sammenstiller Grækenlands og Nordens mytologier ser han deres respektive sjæle i Hades, Poseidon og Zeus overfor Odin, Tor og Tyr (han som "for ærens skyld " vovede sin højre arm da Fenrisulven skulle bindes) - således at de græske guder først og fremmest har deres plads i rummet eller naturen og de nordiske deres $\mathrm{i}$ tiden eller historien. Men ånden $\mathrm{i}$ de to gudeverdener ser han i Kronos over for Balder. Den første var gudefaderen som herskede $i$ en fjern guldalder, men de tre sønner stødte ham fra tronen og delte hans rige. Den anden var jo uskyldens as, dræbt af det egensindige intellekt Loke som brugte den blinde Høder til redskab. 
Hvis alle ville græde for Balder kunne han komme tilbage fra dødsriget, men Loke græd tørre tårer, derfor måtte Balder blive hos Hel. Dog er Balders genkomst det billede hvorunder Grundtvig - svævende "mellem håb og frygt, med lysalfen ved sin højre og mørkalfen ved sin venstre side", for "nutidens lysside: en folkelig opstandelse i oldtidens ånd, er lige så virkelig som dens skyggeside: et vildt oprør mod alt, hvad der sidst havde æren" - forkynder Danmark dets lykketid der skal svinge sig som fugl Føniks af asken:

Hvad forblommet for jeg kvad om Balder,
brustne grave og opstandne folk,
toner klart nu om en Foniks-alder,
åndens nytår som sin egen tolk,
da i stråleglans sig klart forbinde
dåd og dejlighed, som mand og kvinde.

Den lyse opstandelse fra højre (= bevidstgørelse, ikke sublimering) og det mørke oprør fra venstre sætter jeg sammen med nogle dunkle og spredte udtalelser om mennesket der "har en dobbelt verden for sig, den ene tilfælles med dyrene, men den anden med guderne", om "det kredsløb der unægtelig finder sted inden $i$ os alle og er gammel gift med kilden til alt hvad der udstrømmer af os ... vi ser det dybe og hjertelige udvikle sig i Okeaniderne (= verdenshavets døtre), ligesom det høje og andelige i Kroniderne (= Zeus, Poseidon, Hades)" mens derimod ord der "så at sige kun stoppes ind med fingrene ... kommer hverken ovenfra med hvad vi kalder ånden eller nedenfra, fra hvad vi kalder hjertet".

I Balder er det den danske og nordiske fremtid Grundtvig har for øje, for efter at have gæsteoptrådt på den europæiske skueplads i nogle år vender hans tankegang tilbage og holder sig fra nu af indenfor Nordens grænser. Her sker der den forskydning $i$ hans folkehistoriske regnskab at danskere og angelsaksere bliver til ét folk som oprindelig, d.v.s. før folkevandringstiden, hører hjemme i Danmark og har oldingenes Odin som gud - hvorved gubben Grundtvig altså bliver ret en dansker - mens Frej rykker videre til Sverrig og bliver den følelseskerne hvoraf goternes heltegerninger udsprang (og Tor forbliver i Norge). Danskernes 
folk får den plads i Norden som grækerne har i Europa, det danske folk bliver den "hjærtelige drømmerske på havet " og det hænger sammen med at modersmålet har fået tungen på gled i de nyoprettede Stænderforsamlinger og at der med det spirende folkestyre åbner sig udsigt til en dansk højskole.

$\mathrm{Da}$ den så omsider bliver rejst, lader dens grand old man en sjælden gang nogle ord falde inden for skolens mure, og fra disse Taler på Marielyst (udg. af Steen Johansen, 1956) som præges af den overordentlige enkelhed som hos nogle kan være alderdommens frugt, vil jeg til slut anføre et stykke som i al korthed aftegner hele den tænkemåde der som en sød drøm bandt Grundtvig til mytologien gennem hans lange liv:

Ligesom det derfor kun er i vor nærmeste Omkreds, hos os selv og hos vort Folk, i Fædernelandet, vi alle med hinanden tydelig kan see de tre Par Kæmper jeg pegede paa forleden Dag, nemlig Lys og Mørke, Liv og Død, og Sandhed og Løgn, der aldrig kan faa afstridt, saalænge denne Verden staar, saaledes er det ogsaa kun paa vore egne Enemærker vi kan tage varmt Deel i de tre store Agtepars Liv og Levned, Sorger og Glæder, som vi nok veed, findes under alle Himmel-Egne, men maa være os nær for at finde os varme, for disse tre store Ægtepar er Hoved og Hjerte, Folk og Fæderneland, Folkemunden og Billedsproget.

Ja, det er tre yndige Par Ægte-Folk ...,

Ligesom jeg nu forleden Dag viste Dem i vore Hedenske Forfædres Lignelser de tre Par Kæmper som strides til Dommedag i Odins Kamp med Fenris-Ulven, Thors med Midgaards-Ormen og Freis med Surtur, saaledes er det ogsaa nemt at finde de tre Ægtepar, paa hvis Nærværelse og Forligelses-Maal Folkelivets Held og Lykke beror, thi det er aabenbar Odin med Frigga, Thor med Sif og Brage med Idunna.

Ved Odin forstås "levende oplysning både om hvad man ser og hvad der sker". Resten forklarer sig selv - eller er tavshed. 